\title{
The Battle of Britain
}

on Screen 
Titles available and forthcoming in the Societies at War series

War Damage in Western Europe Nicola Lambourne

War Aims in the Second World War

Victor Rothwell

The Battle of Britain on Screen:

'The Few' in British Film and Television Drama

S. P. MacKenzie

British Children's Fiction in the Second World War

Owen Dudley Edwards

The Second World War and Forced Migration Movements in Europe Rainer Schulze

Britain, Ireland and the Second World War

Ian S. Wood

Sweden, the Swastika and Stalin:

The Swedish Experience in the Second World War

John Gilmour

Prisoners of War in the Far East, 1942-45

Kent Fedorowich

Propaganda and War, 1939-45

Robert Cole 


\section{The Battle of Britain on Screen}

'The Few' in British Film and Television Drama

S. P. MacKenzie 
For Lori

S. P. MacKenzie, 2007

Edinburgh University Press Ltd

22 George Square, Edinburgh

Typeset in Melior by

Iolaire Typesetting, Newtonmore, and

printed and bound in Great Britain by

Antony Rowe Ltd, Chippenham, Wilts

A CIP record for this book is available from the British Library

ISBN 9780748623891 (hardback)

ISBN 9780748623907 (paperback)

The right of S. P. MacKenzie

to be identified as author of this work

has been asserted in accordance with

the Copyright, Designs and Patents Act 1988. 